\title{
SMES AND THE GIREULAR ECONOMY: FROM POLICY TO DIFFICULTIES ENGOUNTERED DURING IMPLEMENTATION
}

\author{
Mihaela Ghența ${ }^{1 *}$ and Aniela Matei ${ }^{2}$ \\ ${ }^{1), 2)}$ National Scientific Research Institute for Labour and Social Protection \\ (INCSMPS), Bucharest, Romania
}

Please cite this article as:

Ghența, M. and Matei, A., 2018. SMEs and the Circular Economy: From Policy to Difficulties Encountered During Implementation. Amfiteatru Economic, 20(48), pp. 294-309.

Article History

Received: 7 December 2017

Revised: 4 March 2018

Accepted: 6 April 2018

DOI: $10.24818 / \mathrm{EA} / 2018 / 48 / 294$

\begin{abstract}
Circular economy is a concept that currently received a particular attention due to its contribution to the European objectives related to economic development under restrictive environmental conditions, in other words, the implementation of circular economy activities is essential to maintain and increase the competitiveness of the European economy. The aim of this paper is to contribute to the understanding of the concept of circular economy, of its different dimensions, and in the same time of the difficulties experienced by small and medium-sized enterprises in the process of implementing such activities, at national level. In order to achieve these objectives, data related to the activity of SMEs in Romania regarding circular economy, gathered within Flash Eurobarometer 441 coordinated by the European Commission during April 2016, were analysed. Although the European Union supports the green initiatives of small and medium-sized enterprises and encourages Member States to have similar behaviour, this paper concludes that national policies need to pay more attention to the training of workers and to support the development of the knowledge and professionalism, and concomitantly to reduce the degree of bureaucracy in assessing compliance of the activities carried out by SMEs in the field.
\end{abstract}

Keywords: circular economy, small and medium sized enterprises, resources efficiency, barriers in implementing the circular economy, recycling.

JEL Classification: L26, M10

*Corresponding author, Ghenţa Mihaela - ghenta@incsmps.ro 


\section{Introduction}

This paper aims to contribute to the understanding of the concept of circular economy, its different dimensions, and to the difficulties experienced by small and medium-sized enterprises (SMEs) in the process of implementing the activities specific to the circular economy at national level. The paper first examines the different definitions of the circular economy and identifies various interpretations of the concept in order to later discuss the European vision of the concept of circular economy, including the role of entrepreneurship in creating a European circular economy, especially from the perspective of its contribution to activities such as recycling, recovery, and innovation. Starting from these theoretical aspects and considering the European public policy, the article continues with an analysis of the state of implementation of the circular economy activities at the level of SMEs in Romania (at national and regional level), highlighting the types of activities implemented and barriers that have limited the development of circular economy activities to a greater extent, at national level. The results presented in this article are analysed in correlation with evidence in the literature, with public policy documents, and progress reports that monitor the implementation of circular economy activities at national and European level.

\section{Towards a circular economy - a general approach of the conceptual framework}

Human civilization is currently confronted with a series of challenges generated by the way of consumption and use of natural resources, a pattern perpetuated over the centuries. We are the generations most confronted with the reduction of natural resources and the negative effects of the impact of human activities on the environment and this forces us to change both our thinking and the way we relate to the environment and the economic activities and social issues. The traditional consumption model was based on the use of natural resources as inputs in the economy's activities, followed by the release of waste into the environment. Pearce and Turner propose in 1990 to overcome the usual way of understanding economic activities, the environment and the relationship between these two systems. In this approach, the authors consider the relationship between the environment and the economy to be more than one of a linear interdependence and develop a new economic model, entitled circular economy. The environment performs three functions within the proposed circular economic model: provider of resources for the economic system, assimilator of the waste resulting from economic activities and a direct utility provider in the form of spiritual comfort and aesthetic pleasure. In the context of climate, social and economic transformations, the concept enjoyed increased attention and developed not only in various disciplines, in the scientific literature (Kirchherr et al., 2017) but also in public policy documents (Jun and Xiang, 2011; Rizos et al., 2017), since environmental issues and the interaction between these and economic and social activities are beyond the limits of time and space (Tietenberg and Lewis, 2012). A series of phenomena that are increasingly prevalent in today's society have led to a shift to the circular economy (Ellen McArthur Foundation, 2012; 2013): reducing natural resources and tightening standards for environmental protection, information technology (which makes it possible to identify the resources used and the products throughout the chain of production, manufacture and use), changing consumer behaviour by accepting the sharing of goods and services in exchange for obtaining ownership of them. The interest for this concept has led to the formulation of several definitions: a) circular economy as a complex system based on the theory of the ecological system and on the market economy laws (Wang, 2005); b) circular economy as

Vol. $20 \cdot$ No. $48 \cdot$ May 2018 
an industrial system based on waste disposal, through the use of raw materials, better, superior products and systems, within innovative business models (Beaulieu et al., 2015; Ellen McArthur Foundation, 2013; 2015). Within this system, the consumer becomes a user, which implies a superior performance of products resulting from economic activities (Ellen McArthur Foundation, 2013; 2015). c) circular economy as a system that strikes a balance between economic development, environmental protection and efficient use of the resources available (Jun and Xiang, 2011; Bastein et al., 2013), objective achieved through rational use and high resource efficiency in the process production, reducing the level of pollution, so that the negative effects of human activities on the environment become minimal; d) circular economy as an economic model based on resources' conservation and healthy consumption behaviour (Zhijun and Nailing, 2007); e) circular economy as a model for implementing the notion of sustainable development in the context of transformation of contemporary societies (Geldron, 2014).

The economic circular model has three dimensions that reach three distinct but interlinked systemic levels (Su et al., 2013; Beaulieu et al., 2015): economic, social and environment. In $\mathrm{Su}$ et al. (2013), the economic dimension expresses the contribution of the circular economic model to the increase of the national and regional competitiveness, the environmental dimension envisages the reconfiguration of the industrial platforms in an ecological way, while the social dimension is correlated with the contribution of the circular economic model to the reduction of unemployment problems and improving the quality of life in general. The implementation of the circular economy involves vertical actors (organizations, industrial parks, cities, regions) and horizontal (sectors of economic activity, urban infrastructure, cultural and social environment) (Zhijun and Nailing, 2007, European Commission, 2015a) and is associated with a series of positive effects regarding growth, innovation, the emergence of new jobs, and substantial material cost savings (Ellen McArthur Foundation, 2015).

\section{Circular economy at European level}

At European level, the circular economy is an alternative to the linear development model and is a concept that has developed relatively recently as a solution for achieving the European objectives of economic development under restrictive environmental conditions, in other words, the implementation of circular economy activities is essential to maintaining and increasing the competitiveness of the European Union (European Commission, 2015a).

The European waste recycling policy has contributed to the development of the European circular economic model, in particular by promoting policy and legal measures to support waste recycling and re-use of waste materials in productive processes (European Commission, 2010). In 2011, the European Commission has defined medium and long-term objectives to transform the European economy into a competitive and sustainable one. The transition to the circular economy is the central pillar that supports sustainable, competitive, profitable and resource-efficient development (European Commission, 2011). A description of the concept and means of monitoring progress is then made (European Commission, 2015a, 2015b, 2016), establishing clear responsibilities for Member States in terms of increasing resource efficiency, effective use of the resulting waste, provision of advice and support to small and medium-sized enterprises in the field of resource efficiency and sustainable use (European Commission, 2011). The estimated impacts of the 
implementation of the circular economy at European level will be manifested simultaneously on four levels (Ellen McArthur Foundation, 2015, European Environment Agency, 2016, Rizos et al., 2017): a) at the economic level, by increasing competitiveness, the value of GDP and ensuring a sustainable development of this indicator, as well as supporting innovative initiatives; b) at social level, through integration and social cohesion, increasing the quality of life, changes in consumer behaviour, creating new jobs; c) concerning the environment by reducing the negative and irreversible effects on the climate and the environment and d) in terms of efficient use of resources (reducing the dependence of the European economy on imports of raw materials).

\section{The role of SMEs in implementing the circular economy at European level}

At European level, the contribution of small and medium-sized enterprises to job creation, growth, social stability and innovation is officially recognized and regarded as essential to boost competitiveness. It is admitted that the impact of SMEs on the environment is less investigated (Hillary, 2004). The recognition of the role of SMEs was reflected in a series of European initiatives in order to support their activities, so an official definition of them has been the natural consequence, but also a necessary tool to help SMEs to benefit from the European measures and programs defined to support their development. According to this definition (European Commission, 2003), an enterprise must simultaneously meet conditions regarding the number of employees (less than 250 employees), turnover (50 million euro), total balance sheet value (43 million euro), and access to significant additional resources, as to be considered in the category of small and medium sized enterprises.

In the process of achieving a European circular economy, SMEs and social enterprises have been acknowledged as particularly important, particularly in terms of their contribution to activities such as recycling, repair and innovation (European Commission, 2014, 2015a). Due to the high share of the costs associated with the consumption of raw materials and energy, the European Commission has initiated actions to closely monitor the difficulties that SMEs encounter in the process of transforming the challenges of environmental pollution into opportunities. These efforts have been materialized in an action plan through which the European Union and the Member States intend to support SMEs in exploiting the opportunities for moving to a green economy (European Commission, 2014). In completing European green jobs initiatives, increasing resource efficiency and circulating economy, the European Commission proposed in 2014 a document to support actions specific to green economy implemented by SMEs. The Green Paper on SMEs aims at a more efficient use of all resources and to improve the efficiency of resource use, to encourage entrepreneurship in all types of specific activities to green economy and those specifics to circular economy, exploit the opportunities of environmentally friendly value chains and, last but not least, support the access of green SMEs to the market. In the literature it is appreciated that the barriers encountered by SMEs in the implementation of circular economy specific activities are most frequently related to (Rizos et al., 2015; 2016): a) organizational culture and the management values and attitude towards the environmental issues; b) substantial financial investments related to the implementation of sustainable solutions, from this perspective, access to funds to support sustainable performance and innovation being important; c) lack of adequate government support/appropriate legislation (public funding opportunities, training, appropriate tax policies, etc.); d) lack of information on the benefits of 
implementing a circular economy; e) the high level of bureaucracy in monitoring and reporting data on SMEs performance in the field of circular economy; f) lack of internal technical competencies facilitating the transition to business models that allow for the implementation of sustainable production and consumption technologies; g) insufficient support from suppliers and consumers due to their low interest in environmental issues. Other authors (van Eijk, 2015) synthesize and group the barriers that SMEs encounter in the process of implementing circular economy activities, in relation to the value chain stages (the general framework of conditions needed to make the transition to the circular economy, design and production, consumption, recycling and re-use, logistic) and to the typology of obstacles that may arise (institutional or organizational, cultural and consumption patterns, public policy and legal regulation, access to finance, technology, infrastructure and of economic nature). Ritzén and Sandström (2017) classify the barriers encountered in the process of implementation of the circular economy's principles, as follows: financial (turnover), structural (lack of information, unclear distribution of responsibilities), operational, (infrastructure), attitudinal (risk aversion, perceptions related to the sustainability of actions) and technological. In the category of facilitators of the circular economy, it is mentioned (European Environment Agency, 2016): the development of innovative business models (based on the principles of the circular economy with lasting effects on the economic system); developing policies to support eco initiatives in product design so as to extend the life of the resulting products, recycling and reuse of products, prevention and optimization of the waste management process. A series of empirical studies (Rizos et al., 2016) refers to facilitators such as organizational culture on environmental protection, the management interest in circular economy, government support for the implementation of circular economy activities, recognition by consumers and suppliers of efforts made for the adoption of business models specific to the circular economy, low financial risk to easy the switch from a linear business model to a circular one, adherence to networks in which the concept of business sustainability is promoted and encouraged.

\section{Methodological issues}

\subsection{Research objectives}

Many barriers can hinder the implementation of circular economy activities among SMEs, and these may stem either from their organizational culture or from the market context in which these organisations operate, or from the lack of technical expertise and funding sources. Policy-makers need to better understand the problems faced by SMEs in different sectors of activity and take measures to raise awareness of the benefits and solutions offered by circular economy activities. In order to evaluate the behaviour of Romanian SMEs regarding the activities related to the circular economy, the authors identified the incidence of different types of activities developed by SMEs at national and regional level and analysed the influence of barriers that inhibit the development of circular economic activities using descriptive and inferential statistics procedures.

\subsection{Data source and sample structure}

In order to explore the Romanian SMS's activities in relation with circular economy we use data from Flash Eurobarometer 441 (European Commission, 2016). Data base and the questionnaire are publically available in GESIS Data Archive. The survey was coordinated by European Commission and implemented by TNS during 18-24 April 2016. 
A probabilistic sample has been used, regionally stratified, the questionnaire being applied by CATI technique. The structure of the sample indicates a higher share of SMEs in the regions Bucharest-Ilfov (22.7\%) and North-West (18.3\%). The development regions with the lowest share of SMEs in the structure of the sample are West $(7.5 \%)$ and South-East $(8.2 \%)$ (Table no. 1$)$.

Table no. 1: The structure of the sample

\begin{tabular}{|l|r|r|}
\hline Variables & Number of cases & \% in total sample \\
\hline Regions (NUTS 2) & 49 & 12.2 \\
\hline North-East & 33 & 8.2 \\
\hline South-East & 36 & 9.0 \\
\hline South- Muntenia & 34 & 8.5 \\
\hline South-West Oltenia & 30 & 7,5 \\
\hline West & 73 & 18.3 \\
\hline Nord-West & 55 & 13.8 \\
\hline Centre & 91 & 22.7 \\
\hline Bucharest- Ilfov & 401 & 100 \\
\hline TOTAL & \multicolumn{2}{|c|}{} \\
\hline SME' s dimension & 352 & 87.9 \\
\hline 1-9 employees & 41 & 10.2 \\
\hline 10-49 employees & 8 & 1.9 \\
\hline 50-250 employees & 401 & 100 \\
\hline TOTAL & \multicolumn{2}{|c|}{} \\
\hline
\end{tabular}

Source: Flash Eurobarometer 441. European SMEs and the Circular Economy. April 2016. TNS

Political \& Social [Producer]; GESIS Data Archive: ZA6779, dataset version 1.0.0. (2016), doi:10.4232/1.12668, weighted basis

\subsection{Methodology}

In order to analyse the factors that influence the decisions of SMEs regarding actions related to the circular economy, statistical analysis methods have been applied allowing for: (1) the national and regional distribution of the types of activities specific to the circular economy that Romanian SMEs have developed or were in their implementation at the time of the survey; (2) the identification of the barriers to the development of circular economy activities starting from the taxonomy used in the Flash Eurobarometer 441 questionnaire and 3) the expansion of the analysis regarding the influence of the barriers to the development of the circular economy by introducing new explanatory factors. If the first two types of analyses were descriptive, a factorial method was applied in the third stage of the analysis, the Principal Component Analysis, that enlargement of the list of barriers for which information was gathered in the questionnaire (lack of human resources, lack of expertise to implement circular economy related activities, complex administrative or legal procedures, cost of meeting regulations or standards, difficulties in accessing finance) with two factors: total turnover and financial resources invested on average in the last 3 years in activities specific to the circular economy. The decision to introduce these two explanatory 
variables in the analysis was made by the authors in order to clarify the influence of different types of barriers which may affect the development of circular economy activities, barriers identified based on the question found in Flash Eurobarometer 441 survey. Principal Component Analysis favours the grouping of variables between which there is a high level of correlation in major components, thus facilitating understanding of the data (Leech et al., 2005; Gorunescu, 2006). In our case, we appreciate that the method allows identification and selection of factors that represent barriers in adopting behaviour of SMEs in line with the principles of circular economy. Within the method, a decision on retaining the main components depends on the percentage of variance for each variable selected and the total cumulative variance of each component. The rotation method used in the building of the main components was Varimax, for making the components easier to interpret, also taking into account the recommendations on the existence of a small number of factor loads for each component (Brown, 2009).

\subsection{Results and discussion}

The investigation conducted in 2016 show that in Romania $62 \%$ of the investigated SMEs declared they had undertaken activities related to the circular economy, this percentage placing Romania on the $21^{\text {st }}$ position in the ranking of the EU-28 member states regarding the implementation of the circular economy activities at the level of the SMEs. In the top of the list is Malta with $95 \%$ declared percentage of activities related to the circular economy, the last place being occupied by Bulgaria with $44 \%$.

4.4.1. Typology of circular economy activities: from the state of fact to the intention of development.

The analysis of Romania's situation in the context of EU-28 member states shows that the share of circular economy activities implemented or under implementation at the level of 2015 by Romanian SMEs follows the model of circular economy activities identified on the average of EU-28, activities related to minimise waste by recycling or reusing waste or selling it to another company being most often used $(41 \%)$. But the percentage value recorded for this type of activity specific for circular economy had, at the same time, the biggest gap compared to the average of the EU-28, 14 percentage points, which places us on the $23^{\text {rd }}$ place on the activities related to minimise waste by recycling or reusing waste or selling it to another company. Data from the Flash Eurobarometer places Malta as a leader in the development of activities use to minimise waste by recycling with an 83.2 percentage points among SMS's. Only for activities related to re-plan of the way water is used to minimise usage and maximise re-usage (18.7 percentage of mention) and to redesign products and services to minimise the use of materials or use recycled materials $(32.9$ percentage of mention) we are slightly above the EU-28 average, in the first case ranked $9^{\text {th }}$ in the Member States' hierarchy, and second in the $14^{\text {th }}$ place. Activities related to use of renewable energy places Romania on the lowest position in the ranking of EU-28 members compared to the other types of circular economy activities, the declared percentage for this type of activity being $7.2 \%\left(25^{\text {th }}\right.$ place $)$.

The regional situation for each of the five types of circular economy activities developed by Romanian SMEs highlights regions with a more alert development rhythms and regions with slightly lower development rhythms. North-West represents the development pole for activities to minimise waste by recycling or reusing waste or selling it to another company 
among SMS's, the declared percentage for this kind of activities specific to the circular economy being of $46.1 \%$, while the South-Muntenia region records the lowest percentage for this type of activity (37.8\%). Region Nord-East shows faster rhythms than the other development regions of the country on the activities to redesign products and services in order to minimise the use of materials or use recycled and on the activities to re-plan of the way water is used to minimise usage and maximise re-usage, while the SMS's from the regions West and South-Muntenia are champions at use of renewable energy activities (Table no. 2).

Table no. 2: Activities of circular economy implemented in the last 3 years or under implementation at the level of 2016

\begin{tabular}{|l|c|c|c|c|c|}
\hline \multicolumn{1}{|c|}{$\begin{array}{c}\text { Activities of circular } \\
\text { economy }\end{array}$} & $\begin{array}{c}\text { Romania } \\
(\%)\end{array}$ & $\begin{array}{c}\text { EU 28 } \\
(\%)\end{array}$ & Difference & $\begin{array}{c}\text { Regions with high } \\
\text { percentages }\end{array}$ & $\begin{array}{c}\text { Regions with } \\
\text { low percentages }\end{array}$ \\
\hline $\begin{array}{l}\text { Minimise waste by } \\
\text { recycling or reusing waste } \\
\text { or selling it to another } \\
\text { company }\end{array}$ & $41 \%$ & $55 \%$ & $-14 \%$ & $\begin{array}{c}\text { Northest } \\
\text { West (42.1\%) }\end{array}$ & $\begin{array}{c}\text { South-West } \\
(36.6 \%) \\
\text { South-Muntenia } \\
(37.8 \%)\end{array}$ \\
\hline $\begin{array}{l}\text { Re-plan energy usage to } \\
\text { minimise consumption }\end{array}$ & $34 \%$ & $38 \%$ & $-4 \%$ & $\begin{array}{c}\text { South-West } \\
\text { Oltenia (45.6\%) } \\
\text { Bucharest-Ilfov } \\
(39.8 \%)\end{array}$ & $\begin{array}{c}\text { Centre (24.9\%) } \\
\text { South-Muntenia } \\
(25.3 \%)\end{array}$ \\
\hline $\begin{array}{l}\text { Redesign products and } \\
\text { services to minimise the } \\
\text { use of materials or use } \\
\text { recycled materials }\end{array}$ & $33 \%$ & $34 \%$ & $-1 \%$ & $\begin{array}{c}\text { North-East } \\
(41.7 \%) \\
\text { North-West } \\
(38.7 \%)\end{array}$ & $\begin{array}{c}\text { South-Muntenia } \\
(17.6 \%) \\
\text { Centre (24.7\%) }\end{array}$ \\
\hline $\begin{array}{l}\text { Re-plan of the way water } \\
\text { is used to minimise usage } \\
\text { and maximise re-usage }\end{array}$ & $19 \%$ & $19 \%$ & $0 \%$ & $\begin{array}{c}\text { North-East } \\
(27.1 \%) \\
\text { South-East (25.8) }\end{array}$ & $\begin{array}{c}\text { Centre (11.3\%) } \\
\text { Bucharest-Ilfov } \\
(12.4 \%)\end{array}$ \\
\hline $\begin{array}{l}\text { Use of renewable energy } \\
\text { Cont }\end{array}$ & $7 \%$ & $16 \%$ & $-9 \%$ & $\begin{array}{c}\text { West (36.8\%) } \\
\text { South-Muntenia } \\
(27.9)\end{array}$ & $\begin{array}{c}\text { North-East } \\
(4.5 \%) \\
\text { Centre (5.4\%) }\end{array}$ \\
\hline
\end{tabular}

Source: Flash Eurobarometer 441. European SMEs and the Circular Economy. April 2016. TNS

Political \& Social [Producer]; GESIS Data Archive: ZA6779, dataset version 1.0.0. (2016), doi:10.4232/1.12668, weighted basis

The development of these types of activities was done in the context of the existence of the Green Plan of Action for SMS's adopted by the European Commission on 2 July 2014 together with the Circular Economy Package that allowed SMEs to turn environmental challenges into business opportunities. These documents follow the policy set by two other important documents: the Europe 2020 Strategy and the legal framework for small and medium-sized enterprises. Through the Europe 2020 Strategy, clear objectives have been set for the European Union to become a sustainable economy, while the legal framework for small and medium-sized enterprises states that the European Union should help SMEs to seize the opportunities created by the new economic paradigm represented by the green economy. But earlier this year, a European Commission report on the implementation of environmental policies at European level (European Commission, 2017b, p. 5) showed that the circular economy is underdeveloped in our country. Other authors (Zamfir et al., 2017) 
confirm the results of the European report, Romania being also among the European countries with a low level of entrepreneurial activity (Ştefănescu and On, 2012). So it is important to know how interested the business environment in implementing circular economy activities in Romania, is. The Eurobarometer data of 2016 are not encouraging at all. Activities relating to re-plan energy usage to minimise consumption and those relating the use of renewable energy seem to raise the interest of SME's in a slightly higher percentage than the other types of circular economy activities, SMS's from the region South-West showing the highest interest to develop these types of activities. The data should be analysed considering that activities relating to minimise waste by recycling or reusing waste or selling it to another company ranked first as a type of activity developed over the last three years or under implementation at the time of the investigation, the intention to develop consumption rethinking activities being able to drive this type of activity in the near future in Romania on the first place in the structure of circular economy activities (Table no. 3 ).

Table no. 3: Openness to activities of circular economy in Romania

\begin{tabular}{|c|c|c|}
\hline Activities of circular economy & Plans to develop & $\begin{array}{l}\text { Does not intend } \\
\text { to develop }\end{array}$ \\
\hline $\begin{array}{l}\text { Minimise waste by recycling or reusing waste or } \\
\text { selling it to another company }\end{array}$ & $\begin{array}{l}11.9 \% \\
\text { Bucharest-Ilfov } \\
(17 \%)\end{array}$ & $\begin{array}{l}42.3 \% \\
\text { South-Muntenia } \\
(54.2 \%)\end{array}$ \\
\hline Re-plan energy usage to minimise consumption & $\begin{array}{l}23.9 \% \\
\text { South-West Oltenia } \\
(33.7 \%)\end{array}$ & $\begin{array}{c}39.3 \% \\
\text { South-East }(67 \%)\end{array}$ \\
\hline $\begin{array}{l}\text { Redesign products and services to minimise the use } \\
\text { of materials or use recycled materials }\end{array}$ & $\begin{array}{l}15.7 \% \\
\text { South-West Oltenia } \\
(32.3 \%)\end{array}$ & $\begin{array}{c}45.6 \% \\
\text { West }(62.5 \%)\end{array}$ \\
\hline $\begin{array}{l}\text { Re-plan of the way water is used to minimise usage } \\
\text { and maximise re-usage }\end{array}$ & $\begin{array}{c}18.2 \% \\
\text { South-West Oltenia } \\
(27.3 \%) \\
\end{array}$ & $\begin{array}{c}60.6 \% \\
\text { South-Muntenia } \\
(68.9 \%)\end{array}$ \\
\hline Use of renewable energy & $\begin{array}{l}25.2 \% \\
\text { South-West Oltenia } \\
(36.6 \%)\end{array}$ & $\begin{array}{l}64.4 \% \\
\text { North-East/South- } \\
\text { East }(66.7 \%)\end{array}$ \\
\hline
\end{tabular}

\subsubsection{Barriers to the development of circular economy activities}

Why the Romanian SMEs did not develop activities of the circular economy in a higher percentage? The literature (Rizos et al., 2015; 2016, Van Eijk, 2015) identifies various typologies of barriers in carrying out circular economy activities, but in Flash Eurobarometer 441 five main reasons are retained for evaluation (Table 4). Lack of human resources and the lack of expertise to implement these activities were the most often cited reasons for non-implementation of activities in this field. If the lack of specialised human resources was the reason most often cited in developing regions Bucharest-Ilfov $(52.3 \%)$ and North-West (45.2\%), SMS's from the developing region North-West and Centre hold the first positions when referring to expertise to implement these activities, the percentages 
registered standing around 36 percentage points. Analysing the percentage distribution of the reasons that led to non-implementation of some activities specific to the circular economy, it can be noticed that SMEs from the development region South-Muntenia are those who have perceived the implementation of those activities as less problematic. However, we have to take into account that the percentage distributions obtained for the five categories of reasons are expressed also on the basis of the lesser experience in the development of activities specific to the circular economy, region South-Muntenia occupying the penultimate place in the ranking of development regions in Romania when assessing the stage of implementation of these activities by SMEs in the year 2016 . Difficulties in accessing the financing of circular economy activities have been found particularly in the case of SMEs in the development regions North-West and West, these regions ranking $5^{\text {th }}$ and $6^{\text {th }}$ in the hierarchy of the development regions in Romania when evaluating the stage of implementation of these activities (Table no. 4).

Table no. 4: Barriers to the development of circular economy activities

\begin{tabular}{|c|c|c|c|c|}
\hline $\begin{array}{l}\text { Lack of human } \\
\text { resources }\end{array}$ & $\begin{array}{c}\text { Lack of expertise } \\
\text { to implement } \\
\text { these activities }\end{array}$ & $\begin{array}{c}\text { Complex } \\
\text { administrative or } \\
\text { legal procedures }\end{array}$ & $\begin{array}{l}\text { Cost of meeting } \\
\text { regulations or } \\
\text { standards } \\
\end{array}$ & $\begin{array}{c}\text { Difficulties } \\
\text { in accessing } \\
\text { finance }\end{array}$ \\
\hline Total: $38.9 \%$ & Total: $38.0 \%$ & Total: $32.0 \%$ & Total: $33.1 \%$ & $\begin{array}{l}\text { Total: } \\
31.4 \%\end{array}$ \\
\hline $\begin{array}{c}\text { Bucharest-Ilfov } \\
52.3 \% \\
\end{array}$ & $\begin{array}{c}\text { North-West } \\
36.5 \% \\
\end{array}$ & $\begin{array}{c}\text { North-West } \\
36.5 \% \\
\end{array}$ & $\begin{array}{c}\text { North-East } \\
41.2 \% \\
\end{array}$ & $\begin{array}{c}\text { North-West } \\
41.2 \% \\
\end{array}$ \\
\hline $\begin{array}{c}\text { North-West } \\
45,2 \%\end{array}$ & $\begin{array}{c}\text { Centre } \\
36 \% \\
\end{array}$ & $\begin{array}{c}\text { Centre } \\
36 \% \\
\end{array}$ & $\begin{array}{l}\text { West } \\
36,5 \% \\
\end{array}$ & $\begin{array}{l}\text { West } \\
37,8 \% \\
\end{array}$ \\
\hline $\begin{array}{c}\text { South-West } \\
\text { Oltenia } \\
35.1 \%\end{array}$ & $\begin{array}{c}\text { South-West } \\
\text { Oltenia } \\
33.9 \%\end{array}$ & $\begin{array}{c}\text { South-West Oltenia } \\
33.9 \%\end{array}$ & $\begin{array}{l}\text { Centre } \\
34.8 \%\end{array}$ & $\begin{array}{l}\text { Centre } \\
36.2 \%\end{array}$ \\
\hline $\begin{array}{l}\text { Centre } \\
34.8 \%\end{array}$ & $\begin{array}{c}\text { Bucharest-Ilfov } \\
33.5 \%\end{array}$ & $\begin{array}{c}\text { Bucharest-Ilfov } \\
33.5 \%\end{array}$ & $\begin{array}{c}\text { South-East } \\
33.6 \%\end{array}$ & $\begin{array}{c}\text { South-West } \\
\text { Oltenia } \\
35.6 \%\end{array}$ \\
\hline $\begin{array}{l}\text { West } \\
34.5 \%\end{array}$ & $\begin{array}{l}\text { West } \\
31.2 \% \\
\end{array}$ & $\begin{array}{l}\text { West } \\
31.2 \% \\
\end{array}$ & $\begin{array}{c}\text { Bucharest-Ilfov } \\
33.5 \% \\
\end{array}$ & $\begin{array}{c}\text { North-East } \\
29.4 \% \\
\end{array}$ \\
\hline $\begin{array}{c}\text { South-East } \\
33.1 \%\end{array}$ & $\begin{array}{c}\text { South-East } \\
28 \%\end{array}$ & $\begin{array}{c}\text { South-East } \\
28 \%\end{array}$ & $\begin{array}{c}\text { North-West } \\
33.2 \%\end{array}$ & $\begin{array}{c}\text { South-East } \\
25.9 \%\end{array}$ \\
\hline $\begin{array}{c}\text { North-East } \\
29.7 \%\end{array}$ & $\begin{array}{c}\text { North-East } \\
27.7 \%\end{array}$ & $\begin{array}{c}\text { North-East } \\
27.7 \%\end{array}$ & $\begin{array}{c}\text { South-West } \\
\text { Oltenia } \\
29.2 \\
\end{array}$ & $\begin{array}{c}\text { Bucharest- } \\
\text { Ilfov } \\
24.6 \% \\
\end{array}$ \\
\hline $\begin{array}{l}\text { South-Muntenia } \\
\qquad 11 \%\end{array}$ & $\begin{array}{l}\text { South-Muntenia } \\
20.3 \%\end{array}$ & $\begin{array}{l}\text { South-Muntenia } \\
20.3 \%\end{array}$ & $\begin{array}{c}\text { South-Muntenia } \\
18.2 \%\end{array}$ & $\begin{array}{c}\text { South_Munt } \\
\text { enia } \\
19.7 \%\end{array}$ \\
\hline
\end{tabular}

Source: Flash Eurobarometer 441. European SMEs and the Circular Economy. April 2016. TNS

Political \& Social [Producer]; GESIS Data Archive: ZA6779, dataset version 1.0.0. (2016), doi:10.4232/1.12668, weighted basis

Most of the circular economy activities implemented by SMEs in Romania were selffinanced $(72.5 \%)$, this percentage being above the EU-28 average for self-financing of 
circular economy activities, even if the overrun is just only 2 percentage points. Only $1.4 \%$ from the investigated SMS's declared that they have funded their circular economy through non-reimbursable funds, even if financial support to SMEs continues through Cohesion Funds 2014-2020. Starting with January 2017 SME's efforts to access Cohesion Funds are also supported by the European Centre for Excellence in Resource Efficiency for SMEs. The Centre will include a self-assessment tool and will provide networking opportunities and support activities for SMEs and their support organizations. Also in early 2017 a pilot project funded by the European Parliament and implemented by the European Commission was launched to support SMEs in developing the practical capacity to manage circular economy activities and eco-innovation (European Commission, 2017b).

Based on this information, we have decided to expand the analysis of the influence of the barriers to the development of circular economy activities in SMEs who have implemented or are in the process of implementing circular economy activities (N: 247) by introducing two other explanatory factors: total turnover and financial resources invested on average in the last 3 years in activities specific to the circular economy. Decision has been related to the need of additional clarifications regarding the influence of barriers. The result of the Kaiser-Meyer-Olkin Measurement of Sampling Adequacy test $(0.729$, p-value <0.005) indicates a value close to 1 , which leads us to conclude that a factorial analysis is appropriate and we can reduce the number of indicators to explain variability of data. The value of the Bartlett's Test of Sphericity $(103.29 \mathrm{Sig}=0.000)$ is small enough to reject the hypothesis that the variables are uncorrelated, so there is a strong relationship between the selected variables and factorial analysis can be applied (Leech, 2005). Table no. 5 shows that the first two selected components were retained, explaining about $50 \%$ of the variability of the information (48.369\%).

Table no. 5: Total Variance Explained

\begin{tabular}{|c|r|r|r|r|r|r|}
\hline \multirow{2}{*}{ Component } & \multicolumn{5}{|c|}{ Initial Eigenvalues } & \multicolumn{3}{|c|}{ Extraction Sums of Squared Loadings } \\
\cline { 2 - 7 } & Total & \% of Variance & Cumulative \% & Total & \% of Variance & Cumulative \% \\
\hline 1 & 2.293 & 32.752 & 32.752 & 2.293 & 32.752 & 32.752 \\
\hline 2 & 1.093 & 15.618 & 48.369 & 1.093 & 15.618 & 48.369 \\
\hline 3 & 0.947 & 13.534 & 61.903 & & & \\
\hline 4 & 0.803 & 11.468 & 73.371 & & & \\
\hline 5 & 0.748 & 10.686 & 84.057 & & & \\
\hline 6 & 0.665 & 9.497 & 93.554 & & & \\
\hline 7 & 0.451 & 6.446 & 100 & & & \\
\hline Source: Flash Eurobarometer 441. European SMEs and the Circular Economy. April 2016. TNS \\
Political \& Social Producer]; GESIS Data Archive: ZA6779, dataset version 1.0.0. (2016), \\
doi:10.4232/1.12668, weighted basis
\end{tabular}

The first component has a value of 2.293 and determines about one third of the variability of data $(32.752 \%)$, being positively correlated with complex administrative legal procedures, high costs to ensure the compliance of the activities carried out, difficulties in accessing finance and the lack of expertise in implementing circular economy related activities (Table no. 6). The results point to the fact that efforts should be made to facilitate the implementation of legislation and standards into the SMEs activities. The lack of a clear legislative framework, however, often influences the decision of SMEs to implement activities specific to the circular economy. In general, these organisations are much more influenced by regulatory and local authorities with regard to the need of improvement of 
the environmental performance, compared to larger companies (Hillary, 2004). The low value for the correlation coefficient regarding the average financial resources invested in the last 3 years in the circular economy activities proves that managers are conditioning at a low level the implementation of the principles of circular economy to the investments financed based on turnover. The analysis emphasizes the importance of factors related to the costs that SMEs have to bear to ensure compliance with regulations and standards, as well as the importance of complex administrative legal procedures. The development of circular economy activities in SMEs usually involves an expansion of their administrative burden, mainly due to the obligations arising from the implementation of environmental legislation. Administrative activities are a key issue for SMEs and their implementation often requires financial and time resources inaccessible in most cases (OECD, 2010). The second component has a value of 1.093 and determines $15.618 \%$ of the variability, being mostly correlated with the turnover achieved and the financial resources invested by the organizations in the last 3 years and in a lower extent with the human resources (Table no. 6 ). This result highlights the importance of strategies to develop such activities on the medium and long term at the level of SMEs.

Table no. 6: Correlation coefficients related to the variables within the selected main components

\begin{tabular}{|l|r|r|}
\hline \multicolumn{1}{|c|}{ Variables } & \multicolumn{1}{c|}{$\begin{array}{c}\text { Principal } \\
\text { Component 1 }\end{array}$} & $\begin{array}{c}\text { Principal } \\
\text { Component 2 }\end{array}$ \\
\hline Lack of human resources & 0.400 & 0.516 \\
\hline Lack of expertise to implement these activities & 0.575 & 0.091 \\
\hline Complex administrative or legal procedures & 0.741 & 0.017 \\
\hline Cost of meeting regulations or standards & 0.775 & 0.198 \\
\hline Difficulties in accessing finance & 0.680 & -0.037 \\
\hline Total turnover & -0.125 & 0.673 \\
\hline $\begin{array}{l}\text { Financial resources invested on average in the last 3 years } \\
\text { in activities specific to the circular economy }\end{array}$ & 0.128 & 0.694 \\
\hline
\end{tabular}

Source: Flash Eurobarometer 441. European SMEs and the Circular Economy. April 2016. TNS

Political \& Social [Producer]; GESIS Data Archive: ZA6779, dataset version 1.0.0. (2016), doi:10.4232/1.12668, weighted basis

The analysis confirms the typology of barriers identified among European SMEs with regard to the implementation of circular economy activities (Rizos et al., 2015). In the absence of a long-term economic strategy supported by consistent governmental decisions, SMEs in Romania face three major systemic problems: excessive bureaucracy of legal procedures related to the circular economy, inability to develop a dialogue with the regulatory environment and low investment in human capital and innovation activities, issues in line with a number of recent national research (Ghinăraru et al., 2017; Paşnicu, 2017).

\section{Conclusions}

This paper aimed to contribute to the understanding of the concept of circular economy at the level of SMEs in Romania, by identifying the specific activities developed, as well as the barriers that hinder the implementation of this kind of activities. The descriptive analyses used in the first phase have been followed by a factorial analysis that offered additional information regarding the influence of the barriers in the implementation of the 
circular economy activities among SMEs. The results demonstrate that despite the existence of public policy tools and measures designed to facilitate the transition to a circular economy, there are a number of barriers that hinder this move. Most SMEs in Romania mention the lack of human resources and the lack of expertise in the implementation of circular economy activities as the main barriers, but the importance of costs related barriers that SMEs have to bear to ensure compliance with industry regulations and standards and complex administrative legal procedures also has a major role in this process, the results of PCA supporting this influence. In the absence of a clear engagement of management to overcome barriers related to human resources and know-how, resistance to change in SMEs could occur with less positive consequences in terms of attitude towards the circular economy and the ability to perform the necessary innovations that the implementation of this concept requires. We recognize that the understanding of the behaviour of SMEs in Romania with regard to circular economy could be deepened and the barriers to circular economy implementation could be widened, the limitation of our results being related to the variables included in the questionnaire applied in SMEs and to the nature of the data set used in the investigation.

The position occupied by the SMEs in Romania in 2016 regarding the development of circular economy activities, respectively the 21 st place in the ranking of EU-28 member states reflects the recommendations made by the European Union to our country which converge towards the need to speed up the implementation of conditionalities that Romania accepted, the current macroeconomic indicators being not at all favourable. Romania needs to take advantage of the opportunities to finance the circular economy activities. Although the European Union supports the green initiatives of SMEs and encourages Member States to adopt similar measures, this paper shows that national policies need to pay more attention to training of workers and support for development of knowledge, while reducing the degree of bureaucracy in assessing compliance of the activities carried out by SMEs in the field. In conclusion, we appreciate that the implementation of the activities related to circular economy requires the involvement of both managers and policy makers.

\section{References}

Bastein, T., Roelofs, E., Rietveld, E., Hoogendoorn, A., 2013. Opportunities for a Circular Economy in the Netherlands. [pdf] Delft: The Netherlands Organisation for Applied Scientific Research. Available at: <https://www.tno.nl/media/8551/tno-circulareconomy-for-ienm.pdf> [Accessed 23 November 2017].

Beaulieu, L., Durme, G.V., Arpin, M.L., 2015. Circular Economy: A Critical Review of Concepts. [pdf] Montréal: International Reference Centre for the Life Cycle of Products, Processes and Services. Available at: <http://www.ciraig.org/pdf/CIRAIG_Circular_Economy_Literature_Review_Oct2015.p df> [Accessed 23 November 2017].

Brown, J.D., 2009. Choosing the Right Type of Rotation in PCA and EFA. Shiken: JALT Testing \& Evaluation SIG Newsletter, 13(3), pp. 20-25.

Comisia Europeană, 2003. Recomandarea Comisiei (RC) privind definirea microîntreprinderilor și a intreprinderilor mici și mijlocii. [pdf] Jurnalul Oficial al Uniunii Europene nr. 124 din 20 mai 2003. Available at: <https://eurlex.europa.eu/legal- 
content/EN/TXT/?uri=uriserv:OJ.L_.2003.124.01.0036.01.ENG\&toc=OJ:L:2003:124:T OC> [Accessed 23 November 2017].

Ellen MacArthur Foundation, 2012. Towards the Circular Economy. Economic and business rationale for an accelerated t215-227ransition. [pdf] Cowes: Ellen MacArthur Foundation. Available at: <https://www.ellenmacarthurfoundation.org/assets/ downloads/publications/Ellen-MacArthur-Foundation-Towards-the-Circular-Economyvol.1.pdf> [Accessed 25 November 2017].

Ellen MacArthur Foundation, 2013. Towards the Circular Economy. Opportunities for the consumer goods sector. [pdf] Cowes: Ellen McArthur Foundation. Available at: $<$ https://www.ellenmacarthurfoundation.org/assets/downloads/publications/TCE_Repor t-2013.pdf> [Accessed 20 November 2017].

Ellen MacArthur Foundation, 2015. Towards a Circular Economy. Business rationale for an accelerated transition. [pdf] Cowes: Ellen McArthur Foundation. Available at: $<$ https://www.ellenmacarthurfoundation.org/assets/downloads/TCE_Ellen-MacArthurFoundation_9-Dec-2015.pdf > [Accessed 25 November 2017].

European Commission, 2010. Being wise with the waste. The EU's approach to waste management. [pdf] Bruxelles: European Commission. Available at: <http://ec.europa.eu/environment/waste/pdf/WASTE\%20BROCHURE.pdf> [Accessed 3 October 2017].

European Commission COM 2011 / 21 final of 26 January 2011 Communication from the Commission to the European Parliament, the Council, the European Economic and Social Committee and the Committee of the Regions, A resource-efficient Europe Flagship initiative under the Europe 2020 Strategy.

European Commission, 2014. Green action plan for SMEs, Enabling SMEs to turn environmental challenges into business opportunities, Communication from the Commission to the European Parliament, the Council, the European Economic and Social Committee and the Committee of the Regions, COM (2014) 440 final.

European Commission, 2015a. Closing the loop An EU action plan for the Circular Economy, Communication from the Commission to the European Parliament, the Council, the European Economic and Social Committee and the Committee of the Regions, COM (2015) 614 final.

European Commission, 2015b. Closing the loop An EU action plan for the Circular Economy - Annex, Communication from the Commission to the European Parliament, the Council, the European Economic and Social Committee and the Committee of the Regions, COM (2015) 614 final.

European Commission, 2016. Commission Work Programme 2017, Delivering a Europe that protects, empowers and defends, Communication from the Commission to the European Parliament, the Council, the European Economic and Social Committee and the Committee of the Regions, COM (2016) 710 final.

European Environment Agency, 2016. Circular economy in Europe, Developing the knowledge base. [pdf] Luxemburg: European Environment Agency. Available at: $<$ https://www.eea.europa.eu/publications/circular-economy-in-europe> [Accessed 3 October 2017]. 
European Commission, 2017a. The EU Environmental Implementation Review Country Report - ROMANIA. [pdf] Bruxelles: European Commission. Available at: <http://ec.europa.eu/environment/eir/pdf/factsheet_ro_en.pdf> [Accessed 12 October 2017].

European Commission, 2017b. Report from the Commission to the European Parliament, the Council, the European Economic and Social Committee and the Committee of the Regions on the Implementation of the Circular Economy Action Plan. [pdf] Bruxelles: European Commission. Available at: <http://ec.europa.eu/environment/circulareconomy/implementation_report.pdf> [Accessed 3 October 2017].

Flash Eurobarometer 441. European SMEs and the Circular Economy. April 2016. TNS Political \& Social [Producer]; GESIS Data Archive: ZA6779, dataset version 1.0.0. (2016), doi:10.4232/1.12668

Geldron, A., 2014. Économie circulaire: notions. [pdf] Paris: Agence de l'Environnement et de la Maîtrise de l'Energie. Available at: <http://www.ademe.fr/sites/default/files/ assets/documents/fiche-technique-economie-circulaire-oct-2014.pdf> [Accessed 20 November 2017].

Ghinăraru, C., Ciobanu, C., Matei, A., Sănduleasa, B., Mladen, L., Bădoi, D.G., Ghenţa, M., 2017. Munca atipică în România - vector de competitivitate. Bucureşti: Editura Universitară.

Gorunescu, F., 2006. Data mining. Concepte, modele şi tehnici. Cluj-Napoca: Editura Albastră.

Hillary, R., 2004. Environmental management systems and the smaller enterprise. Journal of Cleaner Production, 12, pp. 561-569.

Jun, H. and Xiang, H., 2011. Development of Circular Economy Is A Fundamental Way to Achieve Agriculture Sustainable Development in China. Energy Procedia, 5, pp. 1530 1534.

Kirchherr, J., Reike, D., Hekker, M., 2017. Conceptualizing the circular economy: An analysis of 114 definitions. Resources, Conservation and Recycling, 127, pp. 221-232.

Leech, N.L., Barrett, K.C., Morgan G.A., 2005. SPSS for Intermediate Statistics, Use and Interpretation. 2nd Edition, New Jersey: Lawrence Erlbaum Associates Inc.

OECD, 2010. Regulatory Policy and the Road to Sustainable Growth. [pdf]. Available at: <https://www.oecd.org/regreform/policyconference/46270065.pdf> [Accessed 12 March 2018].

Paşnicu, D., 2017. Lifelong learning in Romanian SMEs with special focus on the small size enterprises. EDULEARN17 Proceedings, pp. 2557-2563.

Pearce, D. and Turner, R.K., 1990. Economics of Natural Resources and the Environment. Baltimore: The John Hopkins University Press.

Ritzén, S. and Sandström G.O., 2017. Barriers to the Circular Economy - integration of perspectives and domains. Procedia CIRP, 64, pp.7-12.

Rizos, V., Behrens, A., Kafyeke, T., Hirschnitz-Garbers, M., Ioannou, A., 2015. The Circular Economy: Barriers and Opportunities for SMEs. [pdf] CEPS Working Document. Available at: <https://www.ceps.eu/publications/circular-economy-barriersand-opportunities-smes> [Accessed 20 November 2017]. 
Rizos, V., Behrens, A., van der Gaast, W., Hofman, E., Ioannou, A., Kafyeke, T., Flamos, A., Rinaldi, R., Papadelis, S., Hirschnitz-Garbers, M., Topi, C., 2016. Implementation of Circular Economy Business Models by Small and Medium-Sized Enterprises (SMEs): Barriers and Enablers. Sustainability, 8, 1212, pp. 1-18.

Rizos, V., Tuokko, K., Behrens, A., 2017. The Circular Economy A review of definitions, processes and impacts. [pdf] CEPS Working Document. Available at: $<$ https://www.ceps.eu/publications/circular-economy-review-definitions-processes-andimpacts> [Accessed 20 November 2017].

Su, B., Heshmati, A., Geng, Y., Yu, X., 2013. A Review of the Circular Economy in China: Moving from Rhetoric to Implementation. Journal of Cleaner Production, 42, pp. 215-227.

Ştefănescu, D. and On, A., 2012. Entrepreneurship and sustainable development in European countries before and during the international crisis. Procedia - Social and Behavioral Sciences, 58, pp. 889 - 898.

Tietenberg, T. H. and Lewis, L., 2012. Environmental \&natural resource economics. New Jersey: Pearson Education.

Van Eijk, F., 2015. Barriers \& Drivers towards a Circular Economy. [pdf] Naarden: Acceleratio. Available <https://www.circulairondernemen.nl/uploadse00e8643951aef8adde612123e824493.pd f> [Accessed 12 October 2017].

Zamfir, A.M., Mocanu, C., Grigorescu, A., 2017. Circular Economy and Decision Models among European SMEs. Sustainability, 9, 1507, pp. 1-15.

Zhijun, F. and Nailing, Y. 2007. Putting a circular economy into practice in China. Sustainability Science, 2(1), pp. 95-101.

Wang, R.S., 2005. Ecological misunderstanding, integrative approach, and potential industries in circular economy transition. Chinese Journal of Applied Ecology, 16(12), pp. 2439-2446. 